\title{
Suillus lapponicus, a new bolete species from northern Finland
}

\author{
HARRI HARMAJA
}

\begin{abstract}
HARMAJA, H. 1978: Suillus lapponicus, a new bolete species from northern Finland. - Karstenia 18: 27-28.

A new species belonging to the family Boletaceae Chev. (Agaricales) is described: Suillus lapponicus Harmaja. It is fairly closely related to S. variegatus (Fr.) Kuntze, from which it differs mainly in the decurrent hymenophore, slightly wider pores, somewhat darker $\mathrm{KOH}$ reaction of the pileus surface and context, larger spores, slightly darker spore wall which becomes red-brown in $\mathrm{KOH}$, and the presence of two kinds of pleurocystidia, both differing from those of $S$. variegatus. $S$. lapponicus is known from one locality in Finnish Lapland, from dry heath forest, apparently forming an ectotrophic mycorrhiza with Pinus sylvestris L. Carminophilic basidial granules and spore wall are reported in $S$. lapponicus.
\end{abstract}

Harri Harmaja, Botanical Museum, University of Helsinki, SF-00170 Helsinki 17, Finland

Suillus lapponicus Harmaja, n. sp. - A Suillo variegato praecipue differt hymenophoro decurrente, poris leniter maioribus, sporis maioribus $(10.0-14.0 \times 3.8-5.0 \mu \mathrm{m})$ et pleurocystidiis dissimilaribus. - Typus: Finland, prov. Kemin Lappi, par. Muonio, Särkijärvi, ca. $280 \mathrm{~m}$ above sea level, two basidiocarps in dry heath forest among Pinus sylvestris, 11.IX.1972 Harri Harmaja (H).

Pileus ca. $5-7 \mathrm{~cm}$ broad, not hygrophanous, ground colour ochraceous yellow to pale brown, beset with medium brown areoles to \pm appressed small scales, \pm plane; surface almost dry.

Stipe 3-4 $42-3 \mathrm{~cm}$, green-yellow, clavate, without annulus, solid, terete; surface dry, mat, glabrous (i.e. without granules or reticulum); at the base some pink tomentum.

Hymenophore decurrent; tubes and pores at first green-yellow, then becoming brown, the colour of the ripe spores; pores rather small, not blueing on touch.

Context (at fairly advanced stage) pinkish, not blueing.

Odour not distinct.

Taste mild.

Macrochemical test. $\mathrm{KOH}(5 \%)$ : dried pileus surface and context chestnut brown.

Spores (in Melzer's reagent unless otherwise indicated) $\quad(8.5-) 10.0-14.0(-15.5) \times 3.8-$ $5.0(-6.0) \mu \mathrm{m}$, often adhering in tetrads and dyads when young but single when ripe, obtuse-based, boletoid in shape; wall smooth, medium brown in water, rather dark red-brown in $\mathrm{KOH}(5 \%)$, inamyloid, strongly dextrinoid in submature spores but indextrinoid in fully ripe ones, remaining dextrinoid longest in the apical half of the spore, strongly cyanophilic, weakly carminophilic, without the slightest trace of germ-pore or callus; hilar appendage ca. $0.6-1.0 \times 0.5-0.9 \mu \mathrm{m}$, often somewhat deformed, hyaline, inamyloid and indextrinoid, cyanophobic but mostly with strongly cyanophilic basal collar in both fairly young and fully ripe spores, carminophobic; contents guttulate; with one mostly central nucleus.

Basidia ca. $20-35 \times 5.0-8.0 \mu \mathrm{m}, \pm$ clavate, with four or two sterigmata; with weakly carminophilic granulation; wall inamyloid and indextrinoid, cyanophobic, carminophobic. Basidia also present on the whole stipe surface, where a continuous caulohymenium is thus formed.

Pleurocystidia of two kinds: (1) Rather infrequent, in groups or sparse fascicles (and even singly?), often collapsed and difficult to observe, subfusiform to broadly clavate to obpyriform, $20-50 \times 7.5-20 \mu \mathrm{m}$, with basal septum, the basal cell not being inflated; wall slightly thickened, hyaline, not encrusted, not staining with Melzer's 
reagent, cotton blue or acetocarmine. (2) Abundant, not in separate groups or fascicles, 30-50 $\mu \mathrm{m}$ long, ampullaceous with a short \pm inflated basal part $5.0-7.0 \mu \mathrm{m}$ in diameter, and a long flexuous \pm filiform neck which is $2.5-5.0 \mu \mathrm{m}$ thick, \pm obtuse at apex, and mostly separated from the basal part by a septum; wall otherwise as in the first-named type but mostly with thin brownish encrustation in varying amounts in the basal part. Caulohymenium without any cystidia.

Cheilocystidia. Long-necked cystidia (see above) also present as cheilocystidia (but possibly absent or collapsed in places).

Hymenophoral trama. Hyphal walls inamyloid and indextrinoid (but pale blue at times observable in places).

Pileus trichoderm similar to that of $S$. variegatus.

Clamp connections absent.

Ecology. Found, emerging from the mineral soil, on barren ground in dry heath forest belonging to the Myrtillus-Calluna-Cladina site type (Kalela 1961), accompanied by the trees Pinus sylvestris, with which it apparently forms an ectotrophic mycorrhiza, and Betula alba. First half of September.

Distribution. The only locality known at present lies in the northern boreal zone (Ahti et al. 1968), ca. $280 \mathrm{~m}$ above sea level. Northern Finland (Lapland).

Discussion. S. lapponicus is rather closely related to $S$. variegatus (Fr.) Kuntze, from which it differs in the following respects: (1) the hymenophore is fairly distinctly decurrent, (2) the pores are slightly wider, (3) the $\mathrm{KOH}$ reaction of the dry pileus surface and context is somewhat darker brown, (4) the spores are fairly distinctly larger, measuring approximately $10.0-14.0 \times 3.8-5.0 \mu \mathrm{m}$, as compared with ca. $7.5-11.0 \times 2.8-4.0 \mu \mathrm{m}$ in $S$. variegatus, (5) the hilar appendage of the spores is larger, ca. $0.6-1.0 \times 0.5-0.9 \mu \mathrm{m}$ versus ca. $0.5-0.7 \times$ $0.4-0.6 \mu \mathrm{m}$, (6) the spore wall (and so obviously the deposit) is slightly darker brown, (7) the spore wall becomes rather dark red-brown in $\mathrm{KOH}$, (8) two kinds of pleurocystidia are present, the ampullaceous non-fasciculate ones being totally absent from S. variegatus, (9) the pleurocystidia of the normal Suillus type are rather infrequent, in sparse groups to fascicles, and broader and partly differently shaped (frequent, in dense fascicles, clavate/subfusiform/filiform and $4-10 \mu \mathrm{m}$ in diameter in S. variegatus).

Other significant differences probably exist between $S$. lapponicus and $S$. variegatus. For instance, in the former the pileus may be smaller on the average, the basidia are most probably larger, the trichodermal hyphae of the pileus may be slightly narrower and possess somewhat thinner walls, and the species apparently has a pronouncedly northern distribution. Blueing was not observed in any part of the basidiocarp of $S$. lapponicus, which would appear a difference from $S$. variegatus, but this character is variable in the latter species and the non-blueing of the present specimen of $S$. lapponicus may be due to non-genetic factors. I have observed green-yellow areas and patches of caulohymenium apparently associated with this colouration on the stipes of some collections of $S$. variegatus also. Because of this variability of $S$. variegatus and the fact that $S$. lapponicus is so far known only from two fruit bodies, it remains uncertain whether a wide green-yellow caulohymenium is a character diagnostic of $S$. lapponicus. Because of this caulohymenium, I did not observe hyphae with amyloid encrustations in the stipe surface of $S$. lapponicus, although these are present in the stipe cortex of $S$. variegatus according to my observations.

The existence of two kinds of cystidia is exceptional in the genus Suillus Gray; the cystidia of almost all the species of the genus occur in dense fascicles.

The presence of a carminophilic spore wall and basidial granules in a bolete is noteworthy, as, until quite recent years, these characters have been considered to occur only in tribe Lyophylleae of the family Tricholomataceae. However, recent studies have revealed these features also in some darkspored species of the Agaricales, carminophilic basidial and cystidial granules having even been reported in a bolete, Tylopilus felleus (Fr.) Karst. (Clémençon 1975).

\section{References}

Ahti, T., Hämet-Ahti, L. \& Jalas, J. 1968: Vegetation zones and their sections in northwestern Europe. Ann. Bot. Fennici 5: 169-211.

Clémencon, H. 1975: Ultrastructure of hymenial cells in two boletes. - Beih. N. Hedwigia 51: 93-98, pls.
$20-23$.

Kalela, A. 1961: Waldvegetationszonen Finnlands und ihre klimatischen Paralleltypen. - Arch. Soc. Zool. Bot. Fennicae Vanamo 16(suppl.): 65-83. 